\title{
Insurgencia popular, oligarquía regional y estado en el Ecuador liberal (1895-1925): la huelga general de Guayaquil, 1922*
}

\author{
Miguel Angel González Leal \\ Universidad de Barcelona
}

Los acontecimientos de Guayaquil, en noviembre de 1922, constituyeron la expresión social más relevante de la crisis económica que, desde la I Guerra Mundial, afectaba al país. Los violentos sucesos supusieron el inicio de un cambio sustantivo en la correlación de las fuerzas sociales y políticas del Ecuador de los años 20; anunciaron el debilitamiento e inmediato final del régimen liberal que, sostenido por la oligarquía cacaotera de la costa ecuatoriana, se había mantenido en el poder desde 1895, a la par que significaron el comienzo de la presencia efectiva de nuevos actores sociales en la escena nacional.

Sin embargo, por sus dimensiones de sacrificio popular y rebeldía ante el Estado, los sucesos han venido representando un auténtico hito fundacional para el movimiento obrero ecuatoriano, motivo que ha propiciado que esta perspectiva haya sido la predominante en la historiografía sobre el tema. En el presente artículo se ofrece una visión que, rebasando los márgenes estrictamente obreros de la cuestión, expone toda la complejidad de este hecho social, frecuentemente obviada, a través de las diversas interrelaciones de los diferentes sectores sociopolíticos que en él participaron.

\section{Introducción}

Entre 1895 y 1925 transcurrió en la historia del Ecuador un período que, políticamente, se caracterizó por el predominio liberal en las instituciones gubernamentales. Durante estos años, y ejerciendo el poder de manera hegemónica, el liberalismo puso en marcha un proyecto nacional que consolidó las hasta entonces endebles estructuras del Estado ecuatoriano, llevando a cabo una política tendente a la modernización del país. ${ }^{1}$ La base económica del proyecto liberal descansaba en la producción y

* Este artículo es fruto de la investigación que vengo realizando sobre el regionalismo político en la costa ecuatoriana, tesis doctoral dirigida por la Dra. Pilar García Jordán, a quien agradezco sus valiosas sugerencias al presente trabajo. Igualmente, hago extensivo mi agradecimiento a todas aquellas personas que facilitaron mi labor en el Ecuador, especialmente a los bibliotecarios del ArchivoBiblioteca "Aurelio Espinosa-Pólit" de Quito y del "Fondo Rolando" de la Biblioteca Municipal de Guayaquil.

1 Véase Ayala Mora, E.: Historia de la Revolución Liberal ecuatoriana, Quito, 1994, págs. 287-323; y Albornoz Peralta, O.: Ecuador: luces y sombras del liberalismo, Quito, 1989, págs. 61-107. 
exportación de cacao, ${ }^{2}$ recurso controlado por la oligarquía agroexportadora de la costa ecuatoriana que, como grupo de poder y desde la ciudad de Guayaquil, impulsó y financió la llegada al poder del liberalismo y se erigió en el principal sostén de los gobiernos de la época. ${ }^{3}$

La crisis económica desencadenada especialmente a raíz de la I Guerra Mundial, con la bajada de los precios internacionales del cacao, ${ }^{4}$ señala la decadencia de este proyecto. Las medidas gubernamentales, de corte monetarista, ${ }^{5}$ no solucionaron las causas estructurales del problema sino que tendieron a contemporizar la situación, manteniendo los márgenes de ganancia de la oligarquía cacaotera frente a otros grupos de poder, importadores e industriales principalmente, y afectando negativamente a la mayor parte de la población. El mantenimiento de esta línea política de actuación económica provocó continuadas protestas que buscaban restringir la influencia política y el predominio económico del grupo agroexportador costeño y que, en último término, auspiciaron la implantación de tenues medidas correctoras de escaso éxito que sirvieron para agudizar y generalizar la oposición al Estado.

En 1922, el Gobierno del presidente José Luis Tamayo afrontaba una difícil situación, con la merma continua de las ganancias netas procedentes del cacao, sin alternativas económicas inmediatas y con el Estado fuertemente endeudado. ${ }^{6} \mathrm{Al}$ descontento de los grupos económicos contrarios a los agroexportadores se añadía la inquietud generalizada de los sectores

2 Ecuador en esta época era uno de los primeros productores de cacao, tanto por el volumen de producción como por la calidad del mismo; Crawford, L.: El Ecuador en la época cacaotera. Respuestas locales al auge y colapso en el ciclo monoexportador, Quito, 1980, págs. 26-28 y 48-50. Los estudios de carácter histórico sobre la economía cacaotera son numerosos, destacando Contreras, C.: El sector exportador de una economía colonial. La Costa del Ecuador: 1760-1830, Quito, 1990; Chiriboga, M.: Jornaleros y gran propietarios en 135 años de exportación cacaotera (1790-1925), Quito, 1980; Guerrero, A.: Los oligarcas del cacao. Ensayo sobre la acumulación originaria en el Ecuador: hacendados cacaoteros, banqueros exportadores y comerciantes en Guayaquil (1890-1910), Quito, 1980.

3 Crawford: El Ecuador.., págs. 116-120.

4 A partir de 1916 la situación se agravó además con la aparición de plagas que afectaron la producción; ibídem, págs. 199-203; Chiriboga: Jornaleros..., págs. 391-394.

5 Un resumen detallado de las mismas puede verse en Carbo, L.A.: Historia monetaria y cambiaria del Ecuador desde la época colonial, Quito, 1978, reimpresión de la 1. a edición de 1953, págs. 70-89.

6 El ministro de Hacienda exponía ese año “...el deplorable estado de crisis que [...deja] entrever, en un mañana no lejano, las pavorosas perspectivas del desastre"; Cucalón, E.: Informe del Ministro de Hacienda y Crédito Público. Parte expositiva, Quito, 1922, pág. 4. En octubre, una hoja volante de significativo título abogaba por la puesta en práctica de soluciones drásticas; Delgado, I.: El principio del fin, Quito, 1922. 
más desfavorecidos de la sociedad que sufrían la amenaza del hambre. Bajo estas circunstancias, en el mes de noviembre tuvo lugar la Huelga General de Guayaquil, ${ }^{7}$ iniciada como una acción puntual sindical frente a la crisis. En pocos días, la crispación y la extensión de las movilizaciones ofrecieron la oportunidad a todos los sectores sociales descontentos de presentar sus demandas ante el Estado desde una posición de fuerza, propiciando que el planteamiento original evolucionase hacia peticiones concretas contra la política económica gubernamental y contra el poder de los agroexportadores.

La presión resultó efectiva y el Gobierno ejecutó las demandas en detrimento de la oligarquía cacaotera. Casi al mismo tiempo, ante la amenaza latente de la progresión de la huelga entre los sectores populares y el temor implícito a una revuelta generalizada en el país, se optó por cercenar el movimiento huelguístico y emprender una feroz represión militar que causó centenares de muertos.

El retorno del control de la situación a manos del Gobierno marcó el final del conflicto. El grupo cacaotero cedía parcelas de poder mientras que el resto de los grupos económicos obtenían concesiones largamente demandadas y el movimiento sindical quedaba debilitado. El Gobierno, por su parte, emergía de la situación en una posición momentáneamente reforzada ante todos los grupos sociales que le permitiría agotar la legislatura pese a las dificultades.

A lo largo del presente trabajo se mostrará cómo en la inicial lucha sindical confluyeron una variada gama de actores e intereses que desarro-

7 Este hecho se ubica en Latinoamérica dentro de un período de auge de los movimientos sociales protagonizados por obreros que proliferaron en casi todos los países del área. Sin embargo y como se verá en el texto, la huelga de Guayaquil presentó unas características singulares que obligan a matizar su inclusión en esta dinámica general. En este sentido y para una contextualización detallada y sintética, véase Pinneo, R.: "Una reinterpretación de la agresividad obrera: el derrumbe de la economía del cacao y la huelga general de Guayaquil en 1922", Revista Ecuatoriana de Historia Económica, n. ${ }^{\circ}$, año IV, Quito, 1990, págs. 99-134. La bibliografía específica sobre el tema es extensa, en especial la realizada desde posiciones ideológicas de izquierdas. Parte de ella, por lo repetitivo de sus contenidos, errores de apreciación histórica o reiteración explicativa, no ha sido tenida en cuenta en este artículo, salvo para cuestiones muy puntuales; Aguirre, M.: La masacre del 15 de noviembre de 1922 y sus enseñanzas, Guayaquil, 1984; Albornoz Peralta, O.: "La masacre del 15 de Noviembre", en mismo autor: Historia del Movimiento Obrero Ecuatoriano, Quito, 1983, págs. 25-37; Frente Obrero Revolucionario: La lucha de clases en el Ecuador: las jornadas de noviembre de 1922, s.l., s.f. [¿1980?]; Movimiento de Izquierda Revolucionaria: Las jornadas de noviembre de 1922, Quito, 1982; Ramos, S.: Rasgos salientes de la tragedia histórica de noviembre de 1922, Guayaquil, 1983 (1. ${ }^{\text {a }}$ edición 1958); Saad, P.: 15 de Noviembre de 1922 y el papel de la clase obrera en el movimiento de liberación del pueblo, Guayaquil, 1972; Ycaza, P.: Noviembre de 1922: crónica de una insurrección popular, Quito, 1988. 
llaron un complejo juego de alianzas y enfrentamientos en torno a la dirección a seguir en la política económica del país. Por un lado, la Huelga General reveló la existencia de un movimiento obrero capaz de efectuar presiones políticas efectivas sobre temas de interés general, constituyéndose desde ese momento en un nuevo factor de poder explícito en la vida política nacional. Por otro lado, los diferentes grupos oligárquicos, que mantuvieron un tenso pulso entre sí y con el Estado con el clamor popular de fondo, buscaron imponer sus concepciones e intereses respectivos que, en esencia, contraponían a diferentes modelos de desenvolvimiento económico. La crisis del modelo agroexportador basado en un solo producto había mostrado la extrema vulnerabilidad de la economía nacional ante los vaivenes de los mercados internacionales. El mantenimiento del modelo y los márgenes de beneficio de los cacaoteros implicaron la adopción de medidas impopulares que perjudicaron el dinamismo del resto de los sectores económicos y agravaron la difícil situación general. Las medidas implantadas bajo la presión de la Huelga General, rompiendo la línea política favorable a la oligarquía cacaotera, supusieron el primer éxito de los demás grupos oligárquicos en su lucha frente a la supremacía económica y política de los agroexportadores costeños. Por último, el Gobierno de la Nación, como responsable directo de la política económica general, se debatió entre las presiones de ambas concepciones económicas, con la amenaza añadida de una revuelta popular. No podía oponerse directamente a sus principales aunque debilitados garantes, la oligarquía cacaotera, pero tampoco podía ignorar la presión de otros grupos oligárquicos ni obviar el clamor popular. Fruto de ello fue su doble papel de fino negociador e implacable represor en los acontecimientos. El Estado liberal, carcomido por su ya larga trayectoria política y golpeado en su base económica por la crisis del cacao, recibió con la Huelga General de Guayaquil la primera señal significativa de que su hegemonía comenzaba a tambalearse.

\section{A modo de crónica: la huelga general ${ }^{8}$}

El final del período de sesiones del Congreso de $1922^{9}$ estuvo marcado por la polémica. Al descontento generado por el escaso resultado

8 Las fuentes utilizadas para elaborar este apartado han sido múltiples. Entre ellas cabe destacar: prensa, diarios El Guante y El Telégrafo de Guayaquil y El Comercio de Quito (publicaciones de tendencia ideológica y procedencia regional diferentes); obras de protagonistas de los sucesos, princi- 
legislativo en cuanto a medidas efectivas para conjurar la crisis económica, se añadió el intento de promulgación de una ley que recortaba el alcance de la autonomía de gobierno de las universidades y que provocó a partir del 29 de septiembre las primeras protestas callejeras en Guayaquil. ${ }^{10}$ En los primeros días de octubre se sucedieron las movilizaciones universitarias con diversos incidentes con la policía, concitando el apoyo de amplios sectores ciudadanos, entre ellos el de las asociaciones obreras, ${ }^{11}$ hasta que el 4 de octubre el Congreso retiró el proyecto de ley que había originado el conflicto.

Días después, tras este primer pulso exitoso con los poderes estatales, se iniciaría un nuevo conflicto de mayor alcance y resonancia. El 17 de octubre, los obreros ferroviarios de Durán, ciudad próxima a Guayaquil donde se encuentra la terminal de la línea de ferrocarril que une a esta ciudad con Quito, presentaron a la empresa que gestionaba el servicio, la Guayaquil and Quito Railway Company, una serie de peticiones labora-

\footnotetext{
palmente Puig Vilazar, C.: “El sacrificio de un pueblo”. 15 de Noviembre de 1922, Guayaquil, 1983 (1. a edición 1923), Federación de Trabajadores Regional Ecuatoriana: Para la Historia. Exposición de la FTRE sobre la actitud obrera en los meses de Octubre y Noviembre de Mil Novecientos Veintidos, Guayaquil, s.f. (reedición del folleto del mismo título incinerado en 1923 por orden del intendente de Policía del Guayas), y Capelo Cabello, A.: 15 de Noviembre de 1922. Una jornada sangrienta, Guayaquil, 1987 (1. a edición 1973); diversos informes ministeriales, mensajes presidenciales y manifiestos de las autoridades locales; e información contrastada procedente de tres estudios realizados desde perspectivas diferentes, Gándara, M.: La Semana Trágica de Guayaquil. Noviembre de 1922, aproximación a la verdad, Quito, 1991; Milk, R.L.: Growth and development of Ecuador's workers organizations, 1895-1944, PhD. Tesis University of Indiana, 1977, págs. 67-95, y Muñoz Vicuña, E.: El 15 de Noviembre de 1922. Su importancia histórica y sus proyecciones, Guayaquil, 1978. Al margen de las anteriores y las citadas en la nota 7, otras obras destacables que abordan el tema son las de Martínez, P.: Guayaquil, noviembre de 1922. Política oligárquica e insurrección popular, Quito, 1988, quien contextualiza acertada, pero brevemente, la situación económica ofreciendo una detallada crónica de los acontecimientos; Ycaza, P.: Historia del movimiento obrero ecuatoriano, volúmen I, Quito, 1984, págs. 141-156; Páez, A.: El anarquismo en el Ecuador, Quito, 1988, págs. 51-72; y Pineo: "Una reinterpretación...". Igualmente es significativa la obra colectiva del Instituto Nacional de Formación Obrera y Campesina (INFOC), que contiene los recuerdos de antiguos dirigentes y participantes del movimiento obrero de esa época, El 15 de Noviembre y la fundación del socialismo relatados por sus protagonistas, 2 volúmenes, Quito, 1988; señalar que los lapsus de memoria y las reelaboraciones personales presentes en esta última obra obligan a su utilización cautelosa.

9 El Congreso ecuatoriano efectuaba sus sesiones en aquella época anualmente, durante un período laxo que abarcaba dos o tres meses a partir del 10 de Agosto de cada año.

10 Guayaquil se convirtió en la abanderada nacional del movimiento universitario. En Quito, los estudiantes abogaban por aceptar la ley y aprovechar los resquicios legales para sortearla aunque, finalmente, se sumarían a la postura guayaquileña; "El conflicto universitario", El Guante, n. ${ }^{\circ} 4382$, Guayaquil, 2/10/22, págs. 1-2; ibídem, n. ${ }^{\circ}$ 4384, Guayaquil, 3/10/22, págs. 1-2.

11 Incluyendo a organizaciones radicales como la Liga Obrera del Guayas; ibídem, n. ${ }^{\circ} 4382$, Guayaquil, 3/10/22, pág. 2.
} 
les. La respuesta de la compañía fue negativa y el día 19 se declararon en huelga. $^{12}$

La acción desde un principio contó con el apoyo de las asociaciones obreras de Guayaquil, que siguieron con atención el desarrollo de los acontecimientos. El interés principal radicaba no sólo en el principal adversario de los huelguistas, la poderosa compañía ferroviaria, sino en el papel que el propio Gobierno de la Nación jugaba en el conflicto como garante directo de los intereses de la empresa. ${ }^{13}$

Al día siguiente, los obreros de otras estaciones ferroviarias secundaron la huelga y el transporte entre la región costera y la sierra quedó progresivamente paralizado, tanto por la negativa de los obreros a incorporarse al trabajo, como por la realización de pequeños actos de sabotaje que obstaculizaron el tráfico. ${ }^{14} \mathrm{El}$ Gobierno intervino militarizando las estaciones y los convoyes, lo que permitió la salida de algunos trenes. Al mismo tiempo, las autoridades locales de Guayaquil ejercieron los primeros intentos de mediación, estériles por la postura intransigente de la compañía. ${ }^{15}$

Mientras se mantenía este pulso, en Guayaquil crecía la expectación conforme pasaban los días. La recientemente constituída Federación de Trabajadores Regional Ecuatoriana (FTRE) realizó una manifestación de apoyo el día $22,{ }^{16}$ y numerosas organizaciones obreras recaudaron fondos de ayuda y publicaron llamamientos de solidaridad, buscando evitar que la empresa ferroviaria cubriese con desempleados los puestos de los huelguistas.

12 Básicamente, se solicitaban reformas en los servicios médicos, el respeto a las leyes de 8 horas de trabajo y accidentes, plazos de aviso en caso de despido y mejoras salariales. Véase el pliego de demandas en Muñoz Vicuña, E.: El 15 de noviembre..., págs. 23-25.

13 La línea ferroviaria, iniciada bajo el mandato de García Moreno (1860-1875), fue construída por una corporación extranjera a un elevado coste para el Ecuador. Terminada en 1908, bajo el impulso personal del presidente Eloy Alfaro, constituyó la pieza esencial del proyecto de modernización liberal y el eje de articulación principal del país. Para examinar el papel de la política ferroviaria en el liberalismo ecuatoriano véase Clark, K.: Railway Building and Nation Building in Ecuador, 1895 to 1930, PhD. Tesis New School for Social Research, 1993.

14 Los obreros negaron su intervención en dichos actos de sabotaje pero, indudablemente, pesaron para que el ejército procediese a custodiar el tendido férreo y las instalaciones. Un aviso de policía prohibió el segundo día de paro el acceso de los huelguistas a los talleres y vías; "La Huelga Ferroviaria", El Guante, n. ${ }^{\circ} 4401$, Guayaquil, 22/10/22, pág. 5.

15 El gerente, J.C. Dobbie, evitó la negociación y presentó excusas para no desplazarse a Durán, actitud que fue comunicada por el gobernador del Guayas, Jorge Pareja, al presidente Tamayo; ibídem.

16 La nueva central obrera había sido constituída el 15 de octubre y la manifestación sería su primera acción pública. Durante la marcha, se entregó al gobernador Pareja y al jefe de la zona militar, general Enrique Barriga, un memorial rechazando a J.C. Dobbie y exigiendo su dimisión; "Memorial de la FTRE al Sr. Gobernador", El Guante, n. ${ }^{\circ}$ 4402, Guayaquil, 23/10/22, pág. 5; FTRE, Para la historia..., pág. 8. Muñoz Vicuña data el día anterior la acción; El 15 de Noviembre..., pág. 33. 
Finalmente, la postura decidida de los huelguistas y la mediación de las autoridades ordenada por el Gobierno, ${ }^{17}$ propiciaron que el día 26 el conflicto se resolviese favorablemente para los obreros al aceptar la compañía todas las demandas, ${ }^{18}$ ante la satisfacción de las organizaciones obreras guayaquileñas.

El interés y la energía desarrollados en el conflicto por la FTRE $^{19}$ contribuyeron a su consolidación y diversos colectivos obreros comenzaron a gestionar futuras reivindicaciones laborales en su seno. Organizados en esta central, el 8 de noviembre presentaron sus demandas laborales los conductores de la Empresa de Carros Urbanos y los obreros de la Empresa de la Luz y Fuerza Eléctrica, empresas que abarcaban el servicio de transporte público de la ciudad, de tracción animal la primera y de tranvías eléctricos la segunda. Los dos grupos en huelga formaron la Gran Asamblea de Trabajadores de las Empresas de la Luz y Fuerza Eléctrica y de Carros Urbanos (GAT), órgano que los representaría durante el conflicto. Las demandas eran moderadas en cuanto a que pedían la estricta aplicación de las leyes laborales en vigor y el alza de los salarios. ${ }^{20}$

Los empresarios rechazaron de entrada las exigencias obreras y el día 9 comenzó la huelga, que paralizó el transporte público de la ciudad. ${ }^{21}$ El mismo día, los abogados Carlos Puig Vilazar y José Vicente Trujillo fueron elegidos como síndicos de los dos colectivos y los obreros admitieron, continuando la pauta exitosa del conflicto ferroviario precedente, la mediación

17 Treviño, D.: Informe que presenta a la nación el ministro de lo interior, policía, municipalidades, obras públicas, correos, telégrafos, teléfonos, etc., Quito, 1923, págs. 8-9. Destaca en especial el papel del general Barriga, quien medió decisivamente para que la compañía aceptase negociar y cuya actuación sería elogiada por las organizaciones obreras. Véase Gándara, M.: La Semana..., págs. 41-52.

18 Entre los factores que explicarían este desenlace hay que destacar la moderación de las demandas obreras y, especialmente, la necesidad imperiosa por parte del Gobierno de mantener la línea en servicio. Igualmente, no es desdeñable la carga nacionalista que presentó el conflicto, al ser la compañía extranjera, factor que tendió a agrupar ideológicamente a gobierno y huelguistas en el mismo bando. En la prensa se consideraba a la línea "una zona extranjera [...] donde no alcanza[ba]n leyes nacionales ni influencia alguna de los Poderes Públicos"; "Sobre un volcán. Puntos de vista en el conflicto del Ferrocarril”, El Guante, n. ${ }^{\circ} 4404$, Guayaquil, 25/10/22, pág. 1.

19 Equivocadamente nombrada como Sociedad Regional Ecuatoriana de Trabajadores por L.E. Milk: Growth and..., pág. 78.

20 Véase Muñoz Vicuña: El 15 de noviembre..., págs. 44-48.

21 En sentido estricto la huelga comenzó por un cierre patronal al impedir las empresas que los trabajadores sacaran los vehículos a la calle; FTRE: Para la historia..., pág. 12, y periódicos del día 10. El alumbrado público fue prolongado durante unos días más por la intervención de las autoridades y las fuerzas del orden. Tras una intensa pugna al respecto, los huelguistas accedieron a mantener dicho servicio; véase especialmente esta cuestión en "La huelga obrera", El Guante, n. ${ }^{\circ}$ 4421, Guayaquil, $10 / 11 / 22$, págs. $1-2$ y 5 . 
gubernamental en las negociaciones. ${ }^{22}$ A partir del mismo día 9, el conflicto adquirió paulatinamente mayores dimensiones, con el inicio de una serie de huelgas parciales producidas al sumarse a la protesta diversos colectivos obreros en solidaridad con los huelguistas. Durante los siguientes días, las conversaciones entre los representantes de los trabajadores y las empresas del transporte fueron desarrollándose en presencia de las autoridades hasta alcanzar un acuerdo previo el día 11, pero la iniciativa empresarial de aceptar las demandas a cambio de aumentar las tarifas de los pasajes, sólo si los huelguistas incluían esta medida en su reclamación, provocó la ruptura de las negociaciones al día siguiente. El lunes 13, la FTRE y la GAT declaraban el paro general..$^{23}$

Paralelamente al conflicto del transporte se había venido desarrollando otro movimiento que, si bien era sostenido desde ámbitos obreros, su finalidad rebasaba las preocupaciones meramente laborales. El 8 de noviembre, la Confederación Obrera del Guayas (COG), la mayor central obrera de la región costera, había celebrado una asamblea abordando la problemática general de la crisis, tras la que solicitó al Gobierno que bajase los tipos de cambio e incautase los giros de moneda extranjera que manejaban libremente los exportadores, medida reclamada con insistencia por el resto de los grupos de poder del país y objeto de frecuente debate público. ${ }^{24}$

22 Los huelguistas fueron comunicando puntualmente las diferentes decisiones tomadas a las autoridades locales y la misma tarde del día 9 los síndicos se reunieron con éllas; "El gran movimiento obrero de Guayaquil", El Telégrafo, n. ${ }^{\circ}$ 13415, Guayaquil, 10/11/22, pág. 5. Desde los primeros momentos del conflicto en la prensa aparecieron editoriales recomendando la conciliación y el arbitraje; "Cuestiones obreras", El Guante, n. ${ }^{\circ} 4421$, Guayaquil, 10/11/22, pág. 1.

23 Paro General. Al pueblo de Guayaquil, pueblo hermano, hoja volante, Guayaquil, 13/11/22; reproducida en Capelo Cabello: 15 de noviembre..., págs. 18-19. La idea de convocar un paro general, si era necesario, ya había sido expresada el día 10; "Circular de la Gran Asamblea de Trabajadores de

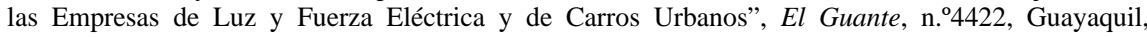
$11 / 11 / 22$, pág. 5 .

24 Los giros provenían principalmente de la venta de cacao en el mercado internacional. Los poseedores de los mismos obtenían un beneficio añadido entregándolos a los bancos para su venta libre. Por un lado, este proceder perjudicaba a los importadores, necesitados de ellos para pagar sus mercaderías, ya que el juego especulativo provocaba el alza del tipo de cambio en razón de la demanda existente de giros, y por otro lado, revertía en el mercado de consumo encareciendo las subsistencias para la gran masa de la población; Crawford: El Ecuador..., págs. 171 y 178-179. Desde semanas antes, los diarios señalaban con insistencia la creciente carestía de los víveres y los problemas que generaba el alza incontrolada del cambio, en especial la especulación que con productos de primera necesidad llevaban a cabo algunos comerciantes. Ante las protestas de organizaciones obreras, el presidente Tamayo dió órdenes para controlar la situación que resultaron fallidas y que contribuyeron a encrespar los ánimos; "El problema de las subsistencias”, El Telégrafo, n. ${ }^{\circ}$ 13393, Guayaquil, 19/10/22, pág. 1. La cuestión del cambio y su impacto social eran temas que constituían objeto de preocupación del Ejecutivo y Tamayo inició el 10 de Agosto el Congreso de ese año con un largo discurso abordando el problema; Actas de Congreso Pleno, tomo I, Archivo del Palacio Legislativo, [1922.1.CoP], Quito, 1922, fols. 2-6. 
La COG consideraba la cuestión del tipo de cambio y los giros como la principal causa de las dificultades que afectaban a los obreros y por ello, prioritaria a cualquier demanda salarial. Defendiendo esta posición, emprendió una serie de acciones que incluyeron la constitución de una asamblea permanente, la difusión de comunicados y la elevación al Gobierno de un memorial analizando el problema y proponiendo la incautación total de los giros, iniciativa de la COG que contó con el soporte y la firma de las principales entidades económicas de la ciudad. ${ }^{25}$ La cuestión del cambio y los giros tampoco fue ajena a los debates de la GAT; ya el 9 de noviembre, primer día de la huelga del transporte, se trató el tema y el síndico J.V. Trujillo intervino explicando por primera vez la problemática que, posteriormente, continuaría despertando interés en el seno de esta asamblea. ${ }^{26}$

La serie creciente de huelgas parciales, el conflicto dirigido por la FTRE y el movimiento cambiario de la COG, vendrían a confluir el día 13 en un mismo frente culminado con la constitución conjunta de la Gran Asamblea Popular del Trece de Noviembre (en lo sucesivo Asamblea), organismo que declararía la Huelga General, secundando el llamamiento inicial de la FTRE y la GAT pero con las demandas centradas en el cambio y los giros. ${ }^{27}$ Respondiendo a la convocatoria se suspendió inmediatamente el suministro eléctrico nocturno y la actividad laboral se paralizó completamente. $^{28}$

25 "Incautación de giros. Memorial dirigido al presidente de la República", El Telégrafo, n. ${ }^{\circ} 13417$, Guayaquil, 12/11/22, págs. 1 y 4 . El mismo diario ya había presentado una propuesta el día anterior; "Proyecto de El Telégrafo. Decreto Ejecutivo de Incautación de Letras", El Telégrafo, n. ${ }^{\circ} 13416$, Guayaquil, 11/11/22, pág. 3 .

26 "La Huelga Obrera", El Guante, n. ${ }^{\circ}$ 4421, Guayaquil, 10/11/22, pág. 5; Puig Vilazar, C.: El sacrificio..., págs. 35-41, aunque equivoca la fecha y la cifra el día 10. L.E. Milk, por su parte, expone que el día 7 ya se habían tratado estos temas en las reuniones preparatorias de la huelga, aunque no cita fuente; Growth and..., pág. 78. Estas informaciones contradicen la opinión aceptada generalmente que sitúa en el día 13 la inclusión sorpresiva y trágica de la cuestión en la GAT; Guzmán Silva, J.: La hora trágica (15 de Noviembre de 1922) i otros apuntes sobre el Movimiento Obrero, Guayaquil, 1983 (1. a edición 1974), pág. 9; Muñoz Vicuña: El 15 de noviembre..., págs. 62-64. Ya en la manifestación realizada por la GAT y la FTRE el día 10 se llegó a pedir la baja del cambio; "La Huelga Obrera", El Guante, n. ${ }^{\circ}$ 4422, Guayaquil, 11/11/22, pág. 2.

27 Demanda a la que se adhirió la FTRE. La GAT, por su parte, renunció a sus peticiones en favor de esta cuestión; FTRE, Para la historia..., págs. 18-19 y 27; Puig Vilazar: El sacrificio..., pág. 40.

28 El argumento de las autoridades para mantener el alumbrado público descansaba en razones de seguridad frente a los delitos. Sin embargo, el corte eléctrico no confirmó este temor, toda vez que la Asamblea organizó un servicio de orden que funcionó satisfactoriamente; FTRE, Para la historia..., pág. 20. 
El alcance de las nuevas demandas indicó a las autoridades que los acontecimientos habían tomado un giro y unas dimensiones inesperadas, desbordando los márgenes de lo que hasta entonces había parecido un conflicto exclusivamente obrero..$^{29}$ Con las demandas ahora centradas en la incautación de giros, la confluencia de la Asamblea con los sectores económicos opuestos a los exportadores, en tanto la petición de incautación era una reivindicación que apuntaba directamente contra los grupos exportadores que sostenían al Estado y que, implícitamente, beneficiaba a los importadores e industriales, impulsó a destacados hombres de negocios y personalidades públicas a incorporarse abiertamente al movimiento y a diversos empresarios a alentar la huelga de sus trabajadores..$^{30}$ Comenzaron entonces las negociaciones entre los representantes gubernamentales y una comisión designada por la Asamblea al respecto que incluía a los directores de los Bancos del Ecuador y "La Previsora", entidades relacionadas con los círculos importadores e industriales.

El día 14 una impresionante manifestación cívica, nunca antes vista en el país, recorrió las calles de Guayaquil exigiendo la aprobación de las medidas en relación al cambio y los giros. El paro era total. En la mañana del día 15 de noviembre, otra nutrida manifestación volvió a ocupar las calles. Hacia el mediodía, las partes negociadoras llegaron a un acuerdo sobre las demandas aprobando un proyecto del decreto solicitado que se envió por telégrafo al Ejecutivo para su promulgación. Se decidió publicar inmediatamente un bando pero, con el fin de que la Asamblea aprobase las resoluciones, se retrasó su publicación hasta las cuatro de la tarde. Sobre

29 Generalmente, en la abundante bibliografía consultada vienen tratándose los acontecimientos de Guayaquil como si pertenecieran a un único movimiento que, según los diversos autores, evolucionó, mutó, fue manipulado, traicionado o cooptado desde sus originarias posiciones sindicales. La lectura atenta de las fuentes permite matizar estos planteamientos y postular la existencia de dos movimientos urbanos separados, opción elegida en este trabajo. De un lado el movimiento sindical dirigido por la FTRE, y de otro el movimiento cambiario llevado a cabo por la COG, frecuentemente obviado en los estudios. El fracaso de las negociaciones sindicales y la difusión creciente de la propuesta de la COG, incluso en el seno del movimiento dirigido por la FTRE, propiciaron que ambas líneas confluyeran el día 13 en la conformación de la Asamblea y en la declaración de Huelga General. En este sentido no es conveniente aludir a transformaciones en el seno del movimiento obrero, en tanto que previamente ya existía un movimiento paralelo en el ámbito obrero que abogaba por medidas cambiarias, sino de asumir la incorporación de la línea minoritaria sindical a las posiciones mayoritarias sobre el cambio, radicalizadas a partir de ese día.

30 Así, entregaron banderas a los manifestantes, dieron permiso a los obreros que trabajaban a sus órdenes para participar en el paro o garantizaron el cobro de los salarios mientras durase la huelga; "El Gran Movimiento Obrero en Guayaquil”, El Telégrafo, n. ${ }^{\circ}$ 13416, Guayaquil, 11/11/22, pág. 3; "La Huelga Obrera", El Guante, n. ${ }^{\circ} 425$, Guayaquil, 14/11/22, págs. 1-2. 
las tres, se desencadenó la violencia. Durante la mañana, la actividad de un piquete de huelga en una panadería fue interrumpida por la intervención de la policía, que efectuó algunas detenciones. ${ }^{31}$ En las primeras horas de la tarde, buena parte de los grupos que durante la mañana se habían estado manifestando se congregaron ante la Clínica Guayaquil, donde se encontraban el gobernador Pareja y los síndicos de la Asamblea, exigiendo la liberación de los detenidos para, posteriormente y una vez obtenida la conformidad de las autoridades, ${ }^{32}$ avanzar en manifestación hacia el cuartel de policía a recibirlos.

El mismo día 15 de noviembre era también el último de unas elecciones locales que se venían celebrando ${ }^{33}$ y en una mesa electoral cercana a la concentración se produjo un altercado entre los manifestantes y los policías que la custodiaban. A los primeros tiros se sucedieron otros y el destacamento que custodiaba el cuartel de policía al ver la manifestación que se aproximaba comenzó a disparar.Iniciado el tiroteo, el jefe de la zona militar, general Enrique Barriga, ${ }^{34}$ dió la orden de intervenir y se desató la represión con extrema violencia sobre los manifestantes. Durante unas horas la ciudad albergó un campo de batalla desigual convirtiéndose el centro de la misma en una ratonera mortal, con miles de manifestantes y transeúntes encerrados contra el río y cercados con precisión por el ejército y la policía. ${ }^{35}$ Durante el tiroteo se produjeron numerosas acciones de

31 Sobre la acción desencadenante de la represión existen innumerables versiones que varían según los detalles y su procedencia. Sirva de ejemplo El Guante, que publicó en su edición del día 17, la primera en editarse tras los sucesos, al menos cuatro versiones diferentes; "La Huelga Obrera", El Guante, n. ${ }^{\circ} 4426$, Guayaquil, 17/11/22, pág. 2.

32 El síndico J.V. Trujillo prometió a la multitud dicha liberación inmediata ante las autoridades presentes y sin que éstas negasen la iniciativa. Véase Muñoz Vicuña, E.: El 15 de Noviembre..., pág. 74; Puig Vilazar: El sacrificio..., págs. 59-60.

33 Al respecto, el día 10 la GAT había aprobado una moción rechazando la participación electoral de los obreros, buscando evitar que el movimiento fuera acusado de tener móviles políticos; "La Huelga Obrera”, El Guante, n. ${ }^{\circ}$ 4422, Guayaquil, 11/11/22, pág. 5; véase también la opinión del síndico Puig Vilazar: El sacrificio..., pág. 34.

34 El día 11 el Gobierno había reforzado la guarnición de la ciudad desplazando cuatro compañías del batallón "Marañón”. Marcos Gándara, militar de profesión, efectúa un detallado análisis al respecto y cifra en alrededor de 1350 los efectivos armados presentes en Guayaquil a partir de esa fecha; La Semana..., págs. 211-214.

35 Las vivencias angustiantes de algunos testigos de los hechos pueden contrastarse en Castel, A., "La fecha triste: el 15 de Noviembre. Reportaje a un día trágico en la historia de Guayaquil por un testigo", Vistazo, n. ${ }^{\circ}$ 50, Guayaquil, 1959, págs. 44-46 y 90; y Guzmán Silva: La hora..., págs. 12-15. Véanse también las declaraciones de los testigos en el proceso judicial abierto tras los sucesos; Romoleroux, K. y Herrería, I.: Noviembre de 1922. Proceso penal contra el pueblo de Guayaquil, Guayaquil, 1989, págs. 25-116, passim. 
saqueo y otras destinadas a proveerse de armas asaltando los almacenes comerciales, intento severamente reprimido en algunos puntos y que resultó fallido, como queda reflejado en el dato de que la tropa apenas sufrió bajas.

Al caer la tarde, la ciudad estaba bajo el control del ejército y sobre las calles quedaban centenares de cadáveres. ${ }^{36} \mathrm{Al}$ día siguiente el Gobierno publicaba el decreto que ordenaba la incautación de giros y se procedía a la detención y al extrañamiento o confinamiento de los dirigentes de las movilizaciones y otras personas sospechosas de comandarlas. ${ }^{37}$

En el resto del país, durante los días 14 y 15 de noviembre diferentes organizaciones obreras habían comenzado a movilizarse secundando el movimiento de Guayaquil. En Quito, Ambato y Riobamba se realizaron concentraciones que, en el caso de Quito, fueron disueltas por la policía. ${ }^{38}$ La noticia de la masacre provocó nuevos intentos de protesta que fueron rápidamente disueltos. La COG por su parte protestaría vivamente por la represión y la FTRE, detenidos y deportados la mayoría de sus dirigentes, mantendría sin éxito la convocatoria de movilizaciones.

La situación de crisis económica y social persistió en los meses siguientes. ${ }^{39}$ A pesar de la continuidad del gobierno de J.L. Tamayo, quien llegó a agotar su legislatura, la huelga de Guayaquil afectó de forma notable la dinámica establecida por los gobiernos liberales. Apenas tres años más tarde, en julio de 1925, la rebelión de un grupo de jóvenes oficiales progresistas del ejército derribó el gobierno liberal de Gonzalo Córdova, sucesor de Tamayo. Con la Revolución Juliana terminaba el ciclo ininterrumpido de gobierno liberal que había regido el país desde 1895 y el predominio económico-político que, basado en el cacao, había detentado la burguesía agroexportadora de la costa ecuatoriana.

36 El Consejo de Estado concedió esa misma noche Facultades Extraordinarias al Ejecutivo que le permitían en especial poner al Ejército en campaña y vigilar con extrema severidad el orden público con medidas excepcionales; Consejo de Estado, Informe del Honorable... al Congreso Nacional de 1923, Quito, 1923, pág. 3. Sobre el número de víctimas de la represión, las cifras que arrojan los estudios varían enormemente desde un centenar hasta varios miles. A juzgar por las relaciones de muertos y heridos publicadas en aquellos días, la cifra aproximada podría estar en torno a los 200 muertos. Sin embargo, el número real no puede calcularse con exactitud, toda vez que una parte de las víctimas fue enterrada en fosas comunes bajo custodia militar.

37 A lo largo del día 16 aún se demoró la promulgación del decreto, lo que motivó un dramático cruce de telegramas entre la comisión que lo había negociado y el presidente Tamayo; "El Decreto de incautación de Giros", El Guante, n. ${ }^{\circ}$ 4426, Guayaquil, 17/11/22, pág. 1.

38 "Movimiento obrero en Quito", El Guante, n. ${ }^{\circ}$ 4427, Guayaquil, 18/11/22, pág. 1.

39 Los defectos de previsión y las fallas en su aplicación hicieron que en pocos meses el decreto de incautación se convirtiese en una medida infructuosa; Crawford: El Ecuador..., págs. 185-188. 


\section{Los nudos de la trama: actores e intereses}

La Huelga General de Guayaquil constituyó un suceso sumamente complejo por la diversidad de fuerzas sociales presentes simultáneamente en los acontecimientos, circunstancia que podría ayudar a explicar la variedad de interpretaciones y perspectivas que, en función de la importancia dada a unos actores u otros, ha venido alumbrando a lo largo de los años la historiografía ecuatoriana. El presente apartado tiene fundamentalmente el objeto de precisar la variedad y naturaleza de los diferentes participantes en los hechos, exponiendo sus diversas interrelaciones en función de los intereses promovidos y defendidos por unos u otros.

Sin perder la imagen de conjunto que se pretende ofrecer, se examinan en primer lugar las fuerzas sociales de carácter popular, con especial atención al movimiento obrero en su papel de motor de las movilizaciones. Seguidamente, se presta atención al pulso de intereses entre los grupos de poder oligárquicos implicados directa o indirectamente en los sucesos para, a continuación y en tercer lugar, sopesar la función del Estado ecuatoriano, en tanto principal receptor de las diferentes presiones y último órgano decisorio y ejecutor respecto a las concesiones y acciones represivas.

\section{La insurgencia popular: sociedades mutualistas, sindicatos revolucionarios y sectores marginales}

La bonanza económica del ciclo expansivo del cacao había propiciado que en el último tercio del siglo XIX la ciudad y puerto de Guayaquil experimentasen un notable crecimiento a todos los niveles, pasando a convertirse en el centro económico del país. ${ }^{40} \mathrm{El}$ incremento de la población y las nuevas necesidades consecuentes se tradujeron especialmente en el desarrollo de oficios típicamente urbanos - servicios y construcción- y en la eclosión de una incipiente industria destinada a cubrir algunas necesidades básicas, además de generar un significativo sector de empleados y obreros ligados al ámbito comercial exportador e importador. A princi-

40 Véase Rojas, M. y Villavicencio, G.: El proceso urbano de Guayaquil, 1870-1980, QuitoGuayaquil, 1988, pág. 23 y siguientes. Sobre la evolución sociohistórica de la ciudad previa al desarrollo cacaotero consultar Hamerly, M.T.: Historia social y económica de la antigua Provincia de Guayaquil, 1763-1842, Guayaquil, 1987. Para el contexto social y urbano del ciclo de auge del cacao véanse las obras citadas en la nota 2. No ha sido posible el acceso a la tesis de Pineo, R.: The Economic and Social Transformation of Guayaquil, Ecuador, 1870-1925, PhD. Tesis University of California, 1987. 
pios del siglo XX la ciudad albergaba el mayor contingente laboral no agrario del Ecuador y constituía un importante polo de atracción para la mano de obra de todo el país. ${ }^{41}$ Pese al dinamismo en este sentido la capacidad de absorción de trabajadores era limitada, por lo que surgió también un sector de desempleados que se desenvolvía en duras condiciones de vida entre el subempleo y la marginalidad urbanas, el número de los cuales se vio incrementado notablemente por el progresivo deterioro de la situación económica del país durante la segunda década del siglo.

La crisis del ciclo cacaotero a partir de 1914 impactó de forma diversa sobre los diferentes sectores sociales. En el ámbito obrero, la depreciación continua de la moneda condujo a la disminución paulatina del valor relativo de los ingresos, mientras que la inestabilidad y las dificultades económicas generales elevaron la precariedad del empleo y empeoraron las condiciones de trabajo. La situación sin embargo, impulsó el desarrollo, alcance y contenidos del asociacionismo laboral como respuesta frente a la crisis; entre 1914 y 1922 el número de asociaciones creció y los conflictos laborales se sucedieron con frecuencia hasta desembocar la Huelga General de noviembre de $1922 .{ }^{42}$ Dentro del campo de la movilización popular de esta protesta, puede señalarse la presencia de tres sectores específicos, mutualismo, sindicalismo y sectores marginales, que respondieron a intereses diferentes.

El mutualismo comprendía a numerosas asociaciones que agrupaban a los diferentes talleres artesanos de un mismo ramo con fines de socorro mutuo y desarrollo de su actividad productiva ${ }^{43}$ La mayor parte de las

41 Deler, J.P.: Ecuador. Del espacio al Estado nacional, Quito, 1987, págs. 171-182. Un amplio estudio histórico sobre los flujos migratorios es el de Estrada, J.: Regionalismo y migración, Guayaquil, 1977.

42 Ycaza: Historia del movimiento..., págs. 120-125; Milk: Growth and..., págs. 26-31. Para ver el desarrollo histórico, tanto en acciones como en contenido ideológico, del asociacionismo laboral ecuatoriano de principios del siglo XX, pueden consultarse Durán Barba, J.: "Estudio introductorio", en mismo autor, Pensamiento popular ecuatoriano, Quito, 1981, págs. 11-94; Milk: Growth and..., págs. 4-66; Páez: El anarquismo..., págs. 31-51; Ycaza: Historia del movimiento..., págs. 39-141. Síntesis interesantes sobre la cuestión realizadas a partir de otros estudios son Balarezo, H. y Martínez, R.: "El movimiento obrero ecuatoriano y el proceso político (sus orígenes: 1880-1938)", Revista IDIS (Instituto de Investigaciones Sociales), n. ${ }^{\circ}$ 21, Cuenca (Ecuador), mayo de 1989, págs. 187-224; y Robalino Bolle, I.: El sindicalismo en el Ecuador, Quito, 1976, págs. 68-82. Asimismo, son relevantes las opiniones recogidas en INFOC, El 15 de noviembre...

43 Las primeras asociaciones obreras ecuatorianas, de carácter gremial, databan del último tercio del siglo XIX y pronto derivaron hacia formas mutualistas. El acceso al poder del liberalismo en 1895 y su apoyo decidido a este ámbito social, supuso la oportunidad para su consolidación y un crecimiento sin precedentes; Ayala Mora: Historia..., págs. 318-323; Quintero, R. y Silva, E.: Ecuador: una nación en ciernes, tomo I, Quito, 1995 (1. a edición 1991), págs. 338-340. En el período liberal el 
sociedades mutualistas se agrupaban en dos grandes confederaciones con sedes respectivas en las principales ciudades del país: la Confederación Obrera del Guayas (COG) en Guayaquil; y la Sociedad Artística e Industrial de Pichincha (SAIP) en Quito. Ambas entidades encarnaban planteamientos ideológicos diferentes y sostenían vinculaciones con distintos sectores de poder político y económico, de los que dependían en un grado notable. ${ }^{44}$

Las relaciones del mutualismo artesanal guayaquileño con diferentes sectores económicos, especialmente industriales e importadores, incidieron para que, coincidiendo con los primeros momentos de la huelga del transporte, la COG iniciase un movimiento en pro de demandas económicas que eran solicitadas desde hacía años y discutidas con particular intensidad en los meses previos al conflicto. ${ }^{45} \mathrm{Si}$ bien el interés de esta entidad desbordó el campo estrictamente laboral, su movimiento de presión resultó reforzado con la huelga obrera paralela del transporte, conflicto que indirectamente apuntaba a la crisis nacional como culpable y cuya creciente protesta podía concretarse y encauzarse a través de demandas de tipo económico general. Las propuestas de la COG, tanto por la difusión pública previa y la lógica de sus planteamientos, como por la oportunidad del momento, fueron asimiladas con entusiasmo en la Asamblea, propiciando a partir de ese momento la unificación de las dos movilizaciones, huelguística y cambiaria, en un amplio frente social.

En lo que respecta al sindicalismo, la creación de la Federación de Trabajadores Regional Ecuatoriana (FTRE) en octubre de 1922 introdujo

\footnotetext{
asociacionismo obrero adquirió mayor complejidad, tanto en lo relativo al número y variedad de asociaciones como en la diversificación del alcance de sus actividades, que ahora incluían escuelas de formación, asesoramiento jurídico, atención sanitaria básica, etc.; véase para el ámbito guayaquileño la descripción de las diferentes sociedades en Navas, B.: Evolución social del obrero en Guayaquil. Obra histórica, Guayaquil, 1920. Paralelamente, la intervención y el peso en la vida política del obrerismo se plasmó en una incipiente legislación laboral, de limitado alcance, que regulaba horarios y accidentes de trabajo.

44 La SAIP mantenía estrechas relaciones con la Iglesia católica y con el conservadurismo serrano mientras que la COG estaba, por el contrario, muy cercana al liberalismo costeño y alineada frecuentemente con el poder estatal. Esta diferenciación sociopolítica regional minó los sucesivos esfuerzos de crear una gran central unitaria; Milk: Growth and..., págs. 43-66. Para la SAIP véase Chiriboga Alvear, M.: Resumen histórico de la Sociedad Artística e Industrial de Pichincha. 1892-1917, 2 volúmenes, Quito, 1917.

45 Desde el Senado, en Agosto de 1922, se llegó a efectuar un llamamiento a los obreros de Quito y Guayaquil para que luchasen contra la especulación del cambio; Méndez, R.: "Crónicas", El Guante, n. ${ }^{\circ} 4336$, Guayaquil, 18/8/22, pág. 1. En septiembre, la SAIP demandó al Congreso medidas económicas para solucionar la crisis; Milk: Growth and..., págs. 70-71.
} 
un vector nuevo y atractivo, por lo abiertamente reivindicativo, para los sectores más descontentos del asociacionismo laboral guayaquileño. ${ }^{46}$ Sus primeras acciones como sindicato tuvieron lugar inmediatamente, con ocasión de la huelga ferroviaria de Durán, y su éxito favoreció la consolidación de la nueva central que atrajo a su seno a un buen número de organizaciones. ${ }^{47}$ Poco después, la FTRE estaba presente en las primeras asambleas y encabezaba la dirección del movimiento huelguístico del transporte. Su compromiso en los hechos estaba directamente centrado en la lucha sindical a través de la GAT, sin embargo, una serie de factores intervinieron para que la FTRE abandonase la línea sindical y se incorporase al tono mayoritario de las reivindicaciones. Fundamentalmente, la inexperiencia organizativa, producto de la juventud de la organización y la debilidad ideológica de sus planteamientos y, sobre todo, el hecho destacable de que la mayoría de los obreros afiliados a esta organización provenían de una larga tradición mutualista relativamente poco receptiva e inexperta en cuanto a planteamientos revolucionario-proletarios. Estos factores favorecieron la conformación de la Asamblea en el día 13 de noviembre y la suspensión de los reclamos obreros en favor de la reivindicación cambiaria. ${ }^{48}$

En contraste con la abundante historiografía relativa a la presencia del movimiento obrero en los sucesos, el controvertido papel de los sectores

46 En diversos estudios se ha venido subrayando el escaso carácter proletario/clasista del mutualismo y su limitado contenido sindical, como se evidencia en las discusiones de los dos primeros congresos obreros (1909 y 1920); Milk: Growth and..., págs. 58-60; Durán Barba: "Estudio...”, págs. 68-75. Hacia 1920, conforme se profundizaba la crisis, la difusión creciente de ideas anarquistas y socialistas incitaron en determinados círculos de obreros e intelectuales de Guayaquil a que comenzara a plantearse la necesidad de forjar una organización auténticamente sindical, deseo concretado en la fundación de la FTRE, organización de aspiraciones revolucionarias e ideología anarquista. El impulso principal procedía de la Sociedad Cosmopolita de Cacahueros “Tomás Briones" (secadores y cargadores de cacao), que aportó el local para la nueva organización y participó con intensidad en su proceso de constitución, publicando en el mes de Agosto el primer llamamiento para la formación de la central; El Guante, n. ${ }^{\circ}$ 4341, Guayaquil, 23/8/22, pág. 5. La vertiente ideológica de este movimiento ha sido tratada por Páez: El anarquismo..., págs. 45-49. En líneas generales consistía en una mezcla heterodoxa de contenidos socialistas, comunistas y anarquistas salpicados de humanismo cristiano, producto de lo que Páez llama formación de malecón.

47 FTRE, Para la historia..., pág. 11.

48 Posteriormente a los hechos, cundió en la FTRE la sensación de que habían sido traicionados y engañados por la COG; J.A.C.C. [¿Capelo Cabello?]: El Crimen del 15 de Noviembre de 1922, Guayaquil, 1922, págs. 5-6; Véliz, N.: Nuestra palabra, hoja volante, Guayaquil, 1923. La resolución violenta del conflicto supuso un golpe mortal para el anarcosindicalismo ecuatoriano, que acusó sus debilidades internas y las dificultades de un ambiente hostil a las formaciones radicales. Durante los años siguientes su presencia en la vida sindical fue puramente testimonial hasta su completa desaparición en 1934; Páez: El anarquismo..., págs. 72-92. 
marginales en los hechos ha gozado de la más absoluta invisibilidad, cuando no un protagonismo principal que habría justificado la represión en orden a contener desmanes ${ }^{49}$ Como se indicaba anteriormente, el contexto de crisis comportó en Guayaquil un aumento de los desempleados urbanos y la depauperización progresiva de un cada vez más numeroso sector de población que sobrevivía del subempleo, la venta ambulante y la caridad, cuando no de actividades ilegales ${ }^{50} \mathrm{y}$ que, radicado en las áreas pantanosas marginales o hacinado en el interior de las manzanas urbanas, vivía en condiciones miserables.

La participación violenta de estos sectores en la convulsa vida política ecuatoriana fue habitual. ${ }^{51}$ En noviembre de 1922, la posibilidad de mejoras inmediatas en la subsistencia activó su movilización, especialmente a partir de la difusión de los beneficios que traería la implantación de las medidas económicas que se demandaban, incentivada aún más por las alusiones del resto de los sectores que los presentaban como los principales destinatarios de los resultados de la lucha. Durante las protestas, su masiva presencia constituyó el elemento más llamativo y, por supuesto, el que ejerció una mayor presión ocupando el espacio urbano, toda vez que el número real de obreros asalariados en huelga era relativamente escaso. ${ }^{52}$ Sin embargo, su participación fue un arma de doble filo que elevó la presión de la protesta pero que alarmó a las autoridades y justificó el estado de alerta de las unidades militares; fue el temor extremo a una revuelta callejera incontrolable lo que provocó la represión al primer atisbo de amenaza y, sólo entonces, los sectores marginales respondieron aprove-

49 La mayor parte de los estudiosos de la historia del movimiento obrero ecuatoriano engloban en un genérico pueblo a todos estos sectores sociales. Marcos Gándara, siguiendo literalmente las opiniones de la época, no duda en aplicar desprestigiadas teorías de turbas como explicación en su estudio; La Semana..., págs. 215-217. R. Pineo, por su parte, pondera la participación de los sectores marginales en los hechos y dignifica un rol frecuentemente menospreciado; "Una reinterpretación...", págs. 133-134.

50 Entre las que destaca el contrabando a pequeña escala. Sobre esta actividad véase Crawford: El Ecuador..., págs. 100-105.

51 Junto a los campesinos sin tierras constituían una capa social en la que prendía fácilmente la rebelión, bien de manera autónoma, bien cuando era requerido su concurso por diferentes facciones políticas y bajo esperanzas de cambios que, por otro lado, eran sistemáticamente defraudadas con posterioridad. Una síntesis histórica enumerativa y brevemente descriptiva de los movimientos sociales ecuatorianos es la realizada por el Centro de Estudios y Difusión Social (CEDIS) y el Centro de Educación Popular (CEDEP): Historia de las luchas populares, 5 fascículos, Quito, 1985.

52 Estos sectores sin embargo, presentaban una dinámica propia, ajena al control directo de una Asamblea en la que no estaban representados, y que se tradujo en una beligerancia verbal contra el orden establecido que desbordó el tono de mesura que intentaron imponer los huelguistas. 
chando las oportunidades de saqueo recibiendo la mayor carga de la violencia represiva. ${ }^{53}$

Es necesario señalar, sin embargo, la existencia de una descoordinación de fondo entre los diferentes sectores populares que rompe la idea de frente unitario que se ha venido manejando por la historiografía sobre el tema. Pese a que se alcanzaban compromisos y cierta unidad de acción, en último término cada sector actuaba motivado por diferentes criterios, lo que se traducía en una falta de liderazgo claro en el movimiento, en los comunicados independientes de cada organización y en la actitud en las calles de los diversos participantes. ${ }^{54}$

\section{El pulso oligárquico: Agroexportadores e importadores ${ }^{55}$}

El prolongado manejo del recurso económico en el que se basaba la riqueza del país conllevó que la oligarquía cacaotera llegase a la larga a detentar los resortes del control del poder, en especial a través de los préstamos que el Banco Comercial y Agrícola de Guayaquil (BCAG), vinculado a este sector productivo, efectuaba al Estado liberal ${ }^{56}$ Durante la época de máximo auge del ciclo, la influencia de los agroexportadores se

53 Pese a que se ha negado repetidamente, privilegiando la motivación de búsqueda de armas, esta acción sí tuvo lugar y lamentablemente sirvió para legitimar el uso de la violencia represiva; Pareja, J.; Barriga, E., y Mateus, A.: A la nación, hoja volante, Guayaquil, 1922; Patriotas Imparciales: Comentarios de la Semana Trágica, hoja volante, Guayaquil, 1922; Merizalde, J.C. et alter: El Gral. Enrique Barriga ante la Historia, hoja volante, Guayaquil, 1923.

54 Además de estos grupos, es necesario señalar la existencia de un sector de capas medias, conformado por diversos profesionales liberales y pequeños comerciantes, afectado también por el impacto de la crisis y que se alineó con el punto de vista mayoritario de la protesta, a excepción de aquéllos que mantenían vínculos con el sector bancario agroexportador o formaban parte de las estructuras del Estado. Su papel en los sucesos es poco conocido, salvo la intervención de abogados como asesores jurídicos de diversos sectores, la acción humanitaria en socorro de los heridos de médicos y clínicas privadas, y la labor propagandística de los periodistas.

55 La diferenciación entre grupos que se utiliza en función de su actividad económica debe ser manejada con sumo cuidado, evitando considerar los diversos grupos como entes homogéneos. El análisis profundo de la composición de las instituciones representativas de dichos grupos, del accionariado y del flujo de inversiones, deja patente lo arriesgado que resulta establecer divisiones tajantes, en tanto existieron interrelaciones entre los distintos sectores en forma de lazos económicos, parentales o personales; Guerrero: Los oligarcas..., págs. 63-83; Crawford: El Ecuador.., págs. 171-172; Chiriboga: Jornaleros..., págs. 333-343.

56 Este grupo estaba compuesto por los hacendados, los comerciantes exportadores de cacao y los miembros de las instituciones financieras creadas al amparo de esta actividad, además de un sector importador ligado directamente a este grupo; Guerrero: Los oligarcas..., págs. 81-83. Para bibliografía específica véase la nota 2 . 
concentró en el impulso y la financiación de un modelo de Estado favorable al desarrollo de su esfera productiva. Sin embargo, la vulnerabilidad del sistema comenzó a manifestarse a partir de 1907 por la competencia de nuevas zonas productoras y la crisis en los países compradores. ${ }^{57}$ Desde 1912, la dependencia económica del Estado ecuatoriano respecto a este sector se incrementó por las inversiones públicas y los gastos militares, facilitando a los cacaoteros el ejercicio de una mayor presión en demanda de medidas frente a los primeros indicios de crisis. El agravamiento posterior de la misma, con la caída de las exportaciones por la I Guerra Mundial, la amenaza de bancarrota en la hacienda estatal y la aparición de plagas en los cultivos, provocó que en 1914 el Gobierno promulgara la Ley de inconvertibilidad metálica de los billetes de banco, o Ley Moratoria, ${ }^{58}$ que permitió la sobreemisión monetaria del BCAG y produjo un efecto inflacionario que abarató los costes de producción del cacao. Esta medida, junto a otras que dificultaron las importaciones, limitaron las exportaciones de los productos de consumo interno, y mantuvieron un tipo de cambio alto a través de sucesivas devaluaciones, rentabilizando la situación para los agroexportadores pero perjudicando a medio plazo a otros grupos de poder económico..$^{59}$

Entre los grupos más afectados por esta política se encontraban los comerciantes importadores y el nuevo sector industrial surgido al calor de la modernización del país. ${ }^{60}$ Radicados principalmente en Guayaquil, sus instituciones bancarias más representativas eran el Banco del Ecuador (BE) y el Banco "La Previsora" (BLP). Para el desarrollo de sus actividades dependían de los suministros del exterior, razón por la que debieron

57 Una excelente síntesis de esta cuestión es la de Chiriboga, M.: "La crisis del cacao y las respuestas sociales", Difusión Cultural, n. ${ }^{\circ}$ 6, Quito, 1987, págs. 34-40. En 1911 los cacaoteros organizaron la Asociación Nacional de Agricultores, cartel que desarrolló una presión efectiva sobre el Estado ecuatoriano pero que a la larga quedó sometido a la dependencia financiera de la Mercantile Overseas Corporation (MOC), entidad norteamericana que a través de los préstamos a la Asociación ejerció un significativo control sobre el cacao y las finanzas ecuatorianas; Chiriboga: Jornaleros..., págs. 356-359 y 397-405; Crawford: El Ecuador..., págs. 96-99 y 204-211.

58 Por la que se facultaba a los bancos para emitir billetes por encima del respaldo en metálico de sus reservas, medida que salvaba al BCAG de una virtual quiebra y permitía al Estado amortizar sus necesidades financieras; véase la obra crítica de Dillon, L.N.: La crisis económico-financiera del Ecuador, Quito, 1927, págs. 33-52. Sobre las plagas ver Crawford: El Ecuador.., págs. 164-165.

59 Las medidas suponían básicamente compensar las mermas de los ingresos procedentes del cacao con la congelación de los costos locales de producción y la especulación con las divisas obtenidas por la exportación; Chiriboga: Jornaleros..., pág. 342.

60 Véase la síntesis de Quintero y Silva: Ecuador: una nación..., págs. 261-264. 
enfrentar la dificultad de pagar los insumos que necesitaban en una moneda progresivamente devaluada. Sin embargo, lograron mantener ciertos márgenes de maniobra aprovechando los resquicios y oportunidades, recolocando la producción exportable en el mercado interno o incrementando el flujo importador con los EEUU en detrimento de los antiguos proveedores europeos. ${ }^{61}$

En los años previos a 1922, estos grupos habían demandado la fijación del tipo cambiario, controles a la especulación con los giros de divisas y la derogación de la Ley Moratoria, medida ésta reclamada con insistencia desde instituciones bancarias, prensa y diversas organizaciones y colectivos obreros, y rechazada reiteradamente por el Ejecutivo y el sector bancario agroexportador alegando el grave impacto que supondría la supresión de dicha Ley. ${ }^{62}$ Paralelamente, se exigían medidas para nivelar la balanza comercial, la fijación del tipo cambiario de forma que se evitasen las alzas desmesuradas, y controles a la especulación con los giros de divisas. ${ }^{63}$ En 1922, la rápida y pronunciada elevación del tipo de cambio disparó las protestas y el Estado decretó una incautación parcial de los giros y la regulación del cambio a través de un decreto promulgado a inicios del verano, medida que fracasó en pocos meses y fue anulada a principios de otoño

61 El control creciente del mercado del cacao ejercido por EEUU a través de sus corporaciones, facultó un mayor flujo comercial con el Ecuador a menores costes que benefició a los importadores locales; ibídem, págs. 278-280. Por otro lado, se llevó a cabo una política de presión que logró atenuar las restricciones. Por ejemplo, la derogación de la prohibición de exportaciones de productos alimenticios, vetada y reglamentada por Tamayo en diciembre de 1920; Carbo: Historia monetaria..., págs. 107-108.

62 Como ejemplo de la numerosa literatura contraria a la Ley Moratoria véase Boada, J.R.: La situación bancaria del Ecuador, Quito, 1922, págs. 12-13. Para un análisis histórico-económico de las visiones que sobre el tema tenían los principales economistas de la época, véase Marchán, C.: "Crisis nacional, aprovechamiento regional y discriminación social de sus efectos económicos (1920-1927)", en mismo autor (comp.): Crisis y cambios de la economía ecuatoriana en los años veinte, Quito, 1987, págs. 221-260. Pese a que popularmente se identificaba a la Ley Moratoria como la principal causa de la crisis, los economistas, aún los más contrarios a la política gubernamental, no estaban por una derogación súbita y sí por reformas cuidadosas a dicha ley; Estrada, V.E.: ¿Moratoria o conversión?, Guayaquil, 1921, págs. 61-62; Alvarado, M. (Un economista): La República económica, el sentido común y la Moratoria, Guayaquil, 1922, págs. 30-31; Núñez, P. L. y otros: El Proyecto de Reformas a la Ley Moratoria. Representación al Senado de la República, Quito, 1919, págs. 13-22. En septiembre de 1922, la Cámara de Comercio de Guayaquil se opuso a la discusión en el Senado de la supresión de dicha ley, firmando la protesta todos los principales bancos, industriales y comerciantes de Guayaquil; Seminario, M.: "La Moratoria", El Guante, n. " 4355, Guayaquil, 6/9/22, pág. 1; "Nuevas adhesiones", El Guante, n. ${ }^{\circ}$ 4356, Guayaquil, 7/9/22, pág. 1.

63 Véase Estrada, V.E.: Voto razonado del Delegado de la "Compañía de Préstamos y Construcciones” de Quito ante la Junta Consultiva Económica de Guayaquil, Quito, 1920, págs. 2029; Ecuatorianos: La muerte del oro, hoja volante, Quito, 6/9/1922. 
renaciendo con brío las protestas hasta que en noviembre sobrevino la Huelga General. ${ }^{64}$

El día 9 de noviembre la COG abordó públicamente la cuestión cambiaria, iniciando un movimiento de presión al que se incorporaron los grupos de importadores e industriales, demandando la emisión por parte del Gobierno de un decreto de incautación total de giros, medida que forzaría la baja del cambio, facilitaría las importaciones y abarataría el consumo. ${ }^{65}$ A partir del día 13, la Asamblea destacó una comisión negociadora ante el Gobierno en la que participaron Eduardo Game, director del BE, y V.E. Estrada, director del BLP. ${ }^{66}$

La demanda recibió el respaldo generalizado e incluso el BCAG, pertinaz opositor a esta línea de reformas, se adhirió el día 11 a la misma desmarcándose puntualmente de los hacendados cacaoteros en favor del sector de importadores que también representaba. ${ }^{67}$ Ante la presión combinada de la calle y los diferentes grupos, el 15 de noviembre asintió Tamayo a la petición pero casi inmediatamente tuvo lugar la represión. Al día siguiente, el decreto aún no se había promulgado y los banqueros urgieron dramáticamente al presidente la publicación del mismo, a lo que se accedió ese mismo día. ${ }^{68}$

En los meses siguientes, la medida se reveló progresivamente ineficaz a causa de defectos en la formulación y aplicación del decreto, generando

64 Véase sobre esta medida fallida la exposición de J.L. Tamayo: Actas de Congreso..., fols. 4-6; también Crawford: El Ecuador..., págs. 178-180. Ante la frustrante situación, el BE intentó controlar el cambio a través de los giros, política que resultó infructuosa debido la contraoferta al alza

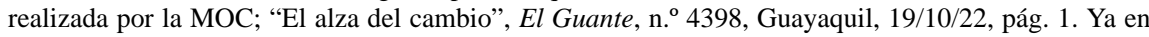
las primeras movilizaciones callejeras de octubre los universitarios lanzaron consignas contra la política económica y la MOC; "El conflicto universitario", El Guante, n. . 4379, Guayaquil, 30/9/22, página 5.

65 Según memoria enviada al presidente Tamayo el día 10: "La baja del cambio", El Guante, n. ${ }^{\circ} 4425$, Guayaquil, 14/11/22, pág. 1.

66 Los efectos positivos que se esperaban de la incautación ofrecieron serias dudas a los representantes obreros, que temían que la medida terminase favoreciendo la especulación con los víveres. Sin embargo, los banqueros ofrecieron vigilar esta cuestión; Puig Vilazar: El sacrificio..., pág. 54; Estrada, V.E.: Memorándum al señor presidente de la república y al señor ministro de hacienda acerca de la cuestión precios durante la incautación, Guayaquil, 1923, pág. 4.

67 "La baja del cambio", El Guante, n. ${ }^{\text {44 }}$, Guayaquil, 14/11/22, pág. 1. Sin embargo, esta fue su única acción en el conflicto y el silencio público presidió su postura. Queda el interrogante de la existencia de contactos reservados con el Ejecutivo que explicarían la demora en aceptar la propuesta de decreto.

68 El decreto de incautación de giros expedido ayer por el Gobierno, hoja volante, Guayaquil, 16 de noviembre de 1922 . 
un aluvión de críticas y demandas. ${ }^{69}$ Pese a ello, constituyó el primer síntoma explícito de que el poder de los hacendados cacaoteros comenzaba a declinar y marcó un límite definitivo al alcance de su influencia política. En 1925, la Revolución Juliana asestó el golpe final al predominio liberalcacaotero, con la implantación de un nuevo régimen político y la reforma bancaria y monetaria que supuso la liquidación del BCAG. ${ }^{70}$

\section{El Estado Liberal entre la ambigüedad y la determinación: de la negociación a la represión}

En 1912, el derrocamiento y posterior asesinato del presidente Eloy Alfaro y sus principales colaboradores apartó violentamente del poder al sector más radical del liberalismo ecuatoriano, eliminando así el más serio intento de cambios estructurales proyectado hasta entonces en el Ecuador. ${ }^{71}$ El magnicidio dio paso a una etapa del liberalismo marcada por la estrecha ligazón de las esferas del poder político y económico que, en torno a Leónidas Plaza, vinculó a grupos económicos costeños y terratenientes serranos. Sin embargo, la progresiva dependencia financiera del Estado respecto al sector bancario agroexportador conllevó la puesta en práctica y el mantenimiento de una política favorable a este sector que, a medio plazo, no resolvió la crisis económica y debilitó las alianzas oligárquicas previas.

En 1920 llegó a la presidencia José Luis Tamayo, abogado guayaquileño relacionado con el BCAG y los importadores, que abrió expectativas respecto a cambios económicos en la situación. ${ }^{72} \mathrm{Su}$ actuación en este sentido fue intensa, aunque estéril, durante los dos primeros años de mandato en los que se preocupó por la especulación cambiaria y por el déficit

69 Crawford: El Ecuador..., págs. 185-189. La medida fue abolida en 1925, a pesar de la encendida defensa que realizó su principal impulsor; Estrada, V.E.: The Incautacion. An Important Financial Essay. Its true meaning and economic functions, Guayaquil, 1923. Véanse las críticas a la aplicación del decreto en Gómez, J.: Breves anotaciones sobre reconstrucción económica nacional, Guayaquil, 1924, págs. 3-5; y Dillon: La crisis..., págs. 97-102. En 1924 se demandó la derogación de la incautación al Congreso y se estudió la propuesta en las Cámaras; Cámara de Diputados: Derogación de la incautación de giros, Quito, 1924.

70 Junto a esta entidad también fue suprimida la Asociación de Agricultores; Crawford: El Ecuador..., págs. 224-227.

71 Ayala Moral: Historia..., págs. 185-200.

72 Ya durante la campaña electoral el nombre de Tamayo apareció asociado a demandas contra la Ley Moratoria; Quiteños: Viva el Gobierno! Abajo la Moratoria!, hoja volante, Quito, 1919. Tras su mandato se publicaron obras laudatorias como La administración del Sr. D. José Luis Tamayo juzgada desde el origen de su candidatura, Quito, 1924; Liberales independientes: El Sr. Dr. José Luis Tamayo ante la historia, hoja volante, Quito, 1924. 
comercial. En los primeros meses de 1922, el alza del cambio llegó a niveles alarmantes y Tamayo decretó en junio la incautación parcial de los giros de divisas, medida cuya escasa efectividad incrementó el descrédito del Gobierno. ${ }^{73}$

En estas circunstancias, la resolución positiva del paro de los ferroviarios en octubre modificó significativamente la imagen de inoperancia gubernativa. Las primeras huelgas de noviembre también recibieron el amparo oficial en las negociaciones; sin embargo, el interés inicial manifestado por el Gobierno se vio sucesivamente desbordado por la generalización del conflicto, la inclusión de la demanda de incautación y la convocatoria de Huelga General. El papel de las autoridades locales sufrió un cambio de contenido, puesto que ya no se trataba de mediar entre obreros y patronos, sino de actuar de receptores de las demandas como representantes del Gobierno. En previsión de la posibilidad de una rebelión que amenazase directamente al poder estatal, se incrementó la dotación militar y, tras las primeras tentativas de garantizar servicios básicos, se cedió a las disposiciones de la Asamblea, aunque manteniendo la vigilancia estratégica.

En la actuación del Ejecutivo durante la huelga pesaba la dependencia que éste tenía respecto a los cacaoteros; no obstante, obviar el insistente clamor callejero, compartido en cierta medida desde el Gobierno, equivalía a acentuar las posibilidades de una revuelta generalizada. Probablemente, la permisividad gubernamental fue un factor que contribuyó al incremento de la presión callejera y garantizó la imposición de las medidas a los agroexportadores, aunque generó el problema, una vez alcanzado el acuerdo, de recuperar el control del orden público. La repentina y brutal represión vino de la mano de la propia escalada de la tensión que ofreció a las autoridades militares la oportunidad de actuar y la justificación a su violenta intervención. ${ }^{74}$ La misma noche del día 15 de noviembre, el Consejo de Estado concedió al Ejecutivo las facultades extraordinarias previstas en la Constitución para casos graves de conmoción interna y que le otorgaron amplios poderes para la seguridad del Estado durante el resto de la legisla-

73 Las críticas al respecto y sobre los males múltiples que esta situación deparaba al país, fueron numerosas. Sirva de ejemplo Delgado, I.: En el abismo, hoja volante, Quito, 1922.

74 En la documentación utilizada no se han hallado indicios de la existencia de un plan previo represivo, aunque puede apreciarse la convicción existente respecto a la necesidad de emprender acciones de fuerza para contener la protesta. Véanse los partes militares recopilados por Gándara: $L a$ Semana..., págs. 176-189. 
tura. ${ }^{75} \mathrm{~A}$ través de esta medida de fuerza, el Estado liberal bloqueó por la vía militar la extensión de la protesta e impuso la continuidad política de un sistema en decadencia. El golpe definitivo al régimen en 1925 vendría precisamente de la mano del ejército, último poder que lo sostenía.

En el marco político gubernamental, merece especial atención la oposición parlamentaria al Gobierno liderada por el senador Enrique Baquerizo Moreno. ${ }^{76}$ Desterrado del país tras los sucesos en unión de otros políticos, su nombre fue asociado a una conspiración que pretendía aprovechar la conmoción creada por la huelga para intentar la toma violenta del poder; esta teoría conspiratoria explicó la evolución de los acontecimientos y legitimó la represión, compartiendo cartel en este sentido con interpretaciones sobre amenazas bolcheviques y turbas desatadas. ${ }^{77}$ No obstante, en las fuentes consultadas no aparecen datos consistentes que permitan asegurar la existencia de una agitación de este tipo; es sólo tras la dramática conclusión cuando sale a la luz la supuesta trama revolucionaria.

\section{Conclusiones}

La Huelga General de 1922 constituyó una coyuntura crítica en la que participaron todas las fuerzas sociales de Guayaquil y cuya repercusión se extendió por toda la República. De forma inequívoca, marcó la inflexión de

75 El Ejército fue declarado en campaña, y se procedió a la detención y al confinamiento de las personas sospechosas de comandar los hechos, abriéndose sumario judicial. Parte del proceso, con las declaraciones tomadas a los diferentes testigos, ha salido a la luz pública en los últimos años gracias a la publicación de Romoleroux y Herrería: Noviembre de 1922. Proceso penal..., págs. 25-116. Las facultades extraordinarias estarían plenamente vigentes hasta el 22 de Mayo del año siguiente en que se retirarían algunas de ellas, siendo confirmada esta decisión y la continuidad de la situación de emergencia por el Congreso de 1923; Informe del Honorable Consejo de Estado al Congreso Nacional de 1923, Quito, 1923, págs. 3-6; Actas de Congreso Pleno de 1923, Archivo del Palacio Legislativo, [1923.8.CoP], Quito, 1923, fols. 8-13 y 51.

76 En su trayectoria política fue además intendente del Guayas y director del BCAG; Gándara: La Semana..., págs. 171-173.

77 Según la versión difundida, emisarios de E. Baquerizo cuestionaron ante la Asamblea los acuerdos alcanzados y aseguraron la complicidad del ejército en un plan revolucionario para derribar al Gobierno. Son abundantes las expresiones y opiniones en esta línea, sirvan de muestra Los ambiciosos en evidencia, hoja volante, Guayaquil, 1922; y Dilettante: Las huelgas y el enriquismo, hoja volante, Guayaquil, 1922. Pese a que el síndico Puig negó la intervención de Baquerizo en el conflicto, la conspiración fue denunciada ante las autoridades judiciales por algunos dirigentes obreros, incluídos los de la FTRE, que se incorporaron así a una corriente que sentenciaba la contaminación del movimiento por elementos políticos ajenos al mismo; Puig: El sacrificio..., págs. 71-72; Romoleroux y Herrería: Noviembre de 1922: Proceso penal..., págs. 100-101. Los conjurados retornaron al país a los pocos meses y continuaron sus labores políticas con normalidad y sin juicios posteriores al respecto e incluso participaron en la discusión del Congreso sobre la actuación del Gobierno en los hechos, en la que se debatió su propio destierro; Actas de Congreso Pleno de 1923, fols. 13-54. 
la alianza liberal-cacaotera que se venía perpetuando en el poder desde 1895, señalando la aparición de nuevos sectores sociales en el panorama político y el ascenso gradual del resto de las élites económicas desvinculadas del proceso de producción y comercialización del cacao. Sectores populares, oligarquía regional y Estado conformaron durante los sucesos una compleja trama de pugnas y alianzas en torno a cuestiones de política económica nacional. A manera de recapitulación, en el ámbito obrero los lazos tradicionales de las organizaciones mutualistas costeras con sectores liberales y grupos de poder oligárquicos, explican la naturalidad del compromiso de la COG en temas económicos ajenos al campo estrictamente sindical, postura por otro lado coherente y consustancial a su manera de entender la lucha obrera. A su vez, el naciente sindicalismo representado por la FTRE manifestó su alcance limitado, principalmente en función de las tendencias mutualistas de su base social. El papel central de esta organización en los inicios de la huelga ha contribuido a que en la historiografía se haya exagerado su actuación en los hechos, sin tomar en cuenta que a partir del día 13 de noviembre su presencia se convierte en puramente testimonial. ${ }^{78}$ Por su parte, los sectores marginales, que constituyeron el grueso de la presión callejera, materializaron en el transcurso del conflicto una comunidad de intereses con la movilización obrera y con las propuestas oligárquicas que prometían el abaratamiento de los víveres. Su concurso fue decisivo para la resolución positiva de las demandas, pero también supuso la inclusión de un elemento de difícil control que sería utilizado como justificante de la intervención militar. ${ }^{79}$

En el ámbito oligárquico cabe señalar las prolongadas relaciones de los cacaoteros con los poderes del Estado y su influencia determinante, en tanto se habían erigido en la base económica principal de la nación. Igualmente, industriales e importadores mantenían relaciones con el Estado

78 Generalmente el papel de la FTRE ha sido, bien ignorado por parte de la historiografía, bien elevado a un papel protagonista que no llegó a alcanzar. Es necesario devolver a su justa medida la intervención de esta central en los sucesos, como bien subraya Durán Barba, J.: "Orígenes del movimiento obrero artesanal", en Ayala Mora, E. (ed.): Nueva historia del Ecuador. Epoca republicana III: cacao, capitalismo y revolución liberal, volúmen 9, Quito, 1989, págs. 194-195. Sin embargo, la capacidad de movilización demostrada por todas las organizaciones obreras y el sangriento final del conflicto, sirvieron como referentes fundamentales para la inminente e inédita constitución de fuerzas políticas de izquierda en la escena política ecuatoriana.

$79 \mathrm{Si}$ puede utilizarse el término de manipulado referido a algún grupo social durante los hechos, habría que pensar necesariamente en los sectores marginales, llamados a la lucha en nombre de unos logros que nunca llegarían a concretarse, para luego sufrir el impacto más violento de la represión. 
de menor proyección, en correspondencia a su papel secundario en la economía, aunque eran grupos en ascenso que representaban la alternativa futura a un sistema económico en decadencia. La Huelga General, apoyada y alentada por diversos empresarios, supuso el respaldo masivo en pos de un proyecto largamente ambicionado que apuntaba directamente a bloquear las acciones de respuesta de los agroexportadores frente a la crisis. El éxito de la misma confirmó el creciente peso en los poderes del Estado de los grupos importadores e industriales y asestó el primer aldabonazo de aviso del inminente final de la hegemonía cacaotera.

En relación a la posición del Estado, es evidente su larga compenetración con las élites cacaoteras y la correlativa instauración de medidas favorables a este grupo en respuesta a la crisis desde 1914. La agudización de los efectos de esta política, unida a la progresiva debilidad del sector cacaotero en contraste con el ascenso de otros grupos oligárquicos, conformaron un complejo panorama para el Estado ecuatoriano respecto a los grupos de presión, obligado a mantener la relación con sus garantes a pesar del clamor del resto de los grupos oligárquicos. El bloqueo de los cacaoteros a los sucesivos intentos estatales por armonizar los intereses de los diferentes grupos, situó al Gobierno en una difícil posición hasta el advenimiento de la Huelga General. El conflicto se erigió, desde el punto de vista estatal, en un justificante insoslayable que permitió imponer de forma radical las medidas que había intentado instaurar anteriormente. Bajo estas circunstancias puede entenderse la permisividad e inacción de las autoridades respecto a la extensión de la protesta y su dramático final en orden a recuperar el control de la ciudad.

Como coyuntura crítica, la Huelga General de Guayaquil supuso el primer signo explícito del declive del poder liberal-cacaotero que, momentáneamente, resolvió violentamente la situación aunque quedó seriamente afectado. La trama de los acontecimientos permite constatar que es difícil sostener la independencia de criterios o acciones generalmente otorgada a los diferentes actores durante los hechos, tal como se ha venido tratando en buena parte de la historiografía sobre el tema. Las interrelaciones presentes muestran que los sucesos evidenciaron una compleja amalgama de intereses en la que estuvieron involucradas todas las fuerzas sociales de la ciudad, y en la que se manifestaron claramente y por vez primera las tendencias de ascenso de nuevos grupos económicos y sociales, frente otras pertenecientes a un sistema económico-político en decadencia al que poco después llegaría su definitivo final. 